\title{
Potential Study of Tidal Stream Turbine Farm at Toyapakeh Strait, Bali
}

\author{
Alamsyah Kurniawan ${ }^{1 *}$, Prayla Putri Annani Barli, Munawir Bintang Pratama1, \\ Ahmad Fitriadhy ${ }^{2}$ \\ ${ }^{1}$ Ocean Engineering Program, Faculty of Civil and Environmental Engineering, Institut Teknologi Bandung \\ Jl. Ganesa No.10, Lb. Siliwangi, Bandung, Jawa Barat 40132, Indonesia \\ 2 Program of Naval Architect, Faculty of Ocean Engineering Technology and Informatics, \\ Universiti Malaysia Terengganu \\ 21300 Kuala Terengganu, Terengganu, Malaysia \\ Email: alamsyah@ocean.itb.ac.id
}

\begin{abstract}
In 2015, Bali Province is mandated by ESDM ministry to become the National Region of Clean Energy, promoting efforts to explore new source of electricity namely tidal stream energy. Previous works have demonstrated that Toyapakeh Strait contains a promising tidal stream resource, with a high stream in a long period. In this study, hydrodynamic modelling and power production analysis is conducted to evaluate this potential with an aim to meet energy demand of Tiga Nusa Cluster Islands. Twenty-one Gen5 KHPS turbines are employed in this study, at an optimized location, $8.72^{\circ} \mathrm{S}, 115.44^{\circ} \mathrm{E}$, which contains the highest energy potential. Financial analysis, with 25 year return period of investment and 3.60\% interest rate, resulting levelized cost of energy (LCOE) of Rp 6,100.kWh . $^{-1}$ This value is higher than the national and regional selling nominal, in other word the energy cost of tidal stream turbine is relatively high in this location. Nearly $46 \%$ of energy cost is spent for turbine fabrication, and from the sensitivity analysis, cutting half the turbine costs may reduce the price by $\mathrm{Rp} 1,400 . \mathrm{kWh}^{-1}$ while increasing the amount of installed turbine is less significant. Despite of the high prices, the study shows that Toyapakeh Strait holds a promising resource of tidal stream energy.
\end{abstract}

Keywords: Marine Energy, Tidal Stream, Hydrodynamic Modelling, Levelized Cost of Energy, Toyapakeh Strait, Bali.

\section{Introduction}

Between the domination of coal and petroleum product, Indonesia targets $23 \%$ of renewable energy shares in the energy mix by 2025 (IRENA, 2017). Solar, wind, biomass, and geothermal plants have shown concrete contribution, while the ocean energy yet to come. Nevertheless, Mukhtasor et al. (2014) reveals that Indonesian water contain a great potential. The wave, tidal stream, and ocean thermal are said to have 1,995 MW, 17,989 MW and 41,001 MW practical potential, respectively.

Among the mentioned sources of ocean energy, the tidal stream is the most advancing and preferred technology due to the predictability and lesson learnt from the wind turbine technology. In Indonesia, some locations have been labelled as promising (Orhan et al., 2016; Firdaus et al., 2017; Pratama et al., 2020) or even feasible for a commercial project (Ajiwibowo et al., 2017a; Firdaus et al., 2019; Mangestiyono et al., 2019; Firdaus et al., 2020; Orhan and Mayerle, 2020). However, only few studies reveal the financial viability of the project (Ajiwibowo et al., 2017b).
This study investigates the potential of tidal stream energy in Toyapakeh Strait located in Bali Province. Following the establishment of Bali Province as a National Clean Energy Area through Decree of the Minister of Energy and Mineral Resources of Republic of Indonesia Number 4421 Year 2015, the province is demanded to prioritize clean energy as one of the primary resources of energy (ESDM Decree No. 4421, 2015). Toyapakeh Strait which separates Nusa Penida and Nusa Lembongan with Nusa Ceningan at the Tiga Nusa Island Cluster, based on previous research, strong stream with speed ranging from $0.5 \mathrm{~m} . \mathrm{s}^{-1}$ to $3.2 \mathrm{~m} . \mathrm{s}^{-1}$ is flowing through this strait (Rachmat and Ilahude, 2017), suitable for the tidal stream energy harvesting site (Mukhtasor et al., 2014; Orhan et al., 2016). Moreover, the cluster is heavily dependent on diesel for generating electricity (Fikri and Hudaya, 2018).

This research aims to assess the system of tidal stream turbine farm in Toyapakeh Strait supplying energy demand of Tiga Nusa Island Cluster. The study does not only involve hydrodynamic modelling and power estimation, but it also provides the investigation on economic viability with financial assessment conducted for 25 years return period. 


\section{Materials and Methods}

The focus of this study is to assess the potential of tidal stream energy in Toyapakeh Strait. The critical step of the study is simulating the tidal stream using Delft3D-FLOW, an open-source numerical modelling tool developed by Deltares (Deltares, 2020b). Tidal stream at potential locations is utilized to rotate tidal turbine and to generate energy. This study is divided into three steps including hydrodynamic modelling, power production estimation, and economic viability analysis.

\section{Hydrodynamic modelling}

Hydrodynamic modelling is conducted using modelling software Delft3D-FLOW which solves the Navier-Stokes equations for an incompressible fluid, within shallow water and the Boussinesq assumptions (Deltares, 2020a). This tool has been widely used to simulate hydrodynamic phenomena in river (Kurniawan et al., 2014), coastal (Kurniawan et al., 2018), and ocean environment (Tay et al., 2016). To properly simulate a narrow Toyapakeh Strait, the hydrodynamic modelling carries out the 2D depth averaged velocities and applies domain decomposition technique for model downscaling. This technique allows a parallel computing of 2 grids (i.e., global dan local domain) with different properties in reducing computing time yet increasing the resolution of the grid. The computational domains are shown in Figure 1.

The model domain uses spherical for the horizontal coordinate systems and depth-averaged sigma layer for the vertical coordinate systems. The global domain extends about $120 \times 120 \mathrm{~km}^{2}$ around Lombok Strait, water area between Bali and Lombok
Islands. Meanwhile, the local domain covers waters around Nusa Lembongan, Ceningan, and Penida Islands (called as Tiga Nusa Cluster). The finest cell resolution in global and local domains are 500x400 $\mathrm{m}^{2}$ and $170 \times 190 \mathrm{~m}^{2}$. Land boundary and the bathymetry is obtained from GEBCO (GEBCO, 2020).

Model only accounts tidal forcing where TPXO 7.2 Global Inverse Tide Model (Egbert and Erofeeva, 2002) generates 13 tidal constituents at the boundary points of global domain (Figure 1). The model is run for fifteen days, providing one spring and neap cycle with 0.05 minutes for computational time step. The water density and viscosity are set to 1025 kg. $\mathrm{m}^{-3}$ and $1 \mathrm{~m}^{2} \cdot \mathrm{s}^{-1}$ (Deltares, 2020a).

\section{Power estimation}

According to Hardisty (2009), the power contained in a moving water $\left(P_{D}(t)\right)$ can be written as equation (1), where $\rho$ is fluid density and $U(t)$ is current velocity.

$$
P_{D}(t)=\frac{1}{2} \rho U(t)^{3}
$$

The produced power of a tidal turbine ( $\left.P_{\text {output }}\right)$ is estimated using equation (2) where $A_{\text {turbine }}$ is swept area and $n_{\text {overall }}$ is device total efficiency.

$$
P_{\text {output }}=A_{\text {turbine }} \times P_{D}(t) \times \eta_{\text {overall }}
$$

The annual mean power production is calculated by averaging the $N$ time of power output $\left(P_{\text {output-i }}\right)$ as expressed in equation (3).

$$
P_{\text {annual-output }}=\frac{\sum_{i=1}^{N} P_{\text {output }-i}}{N}
$$

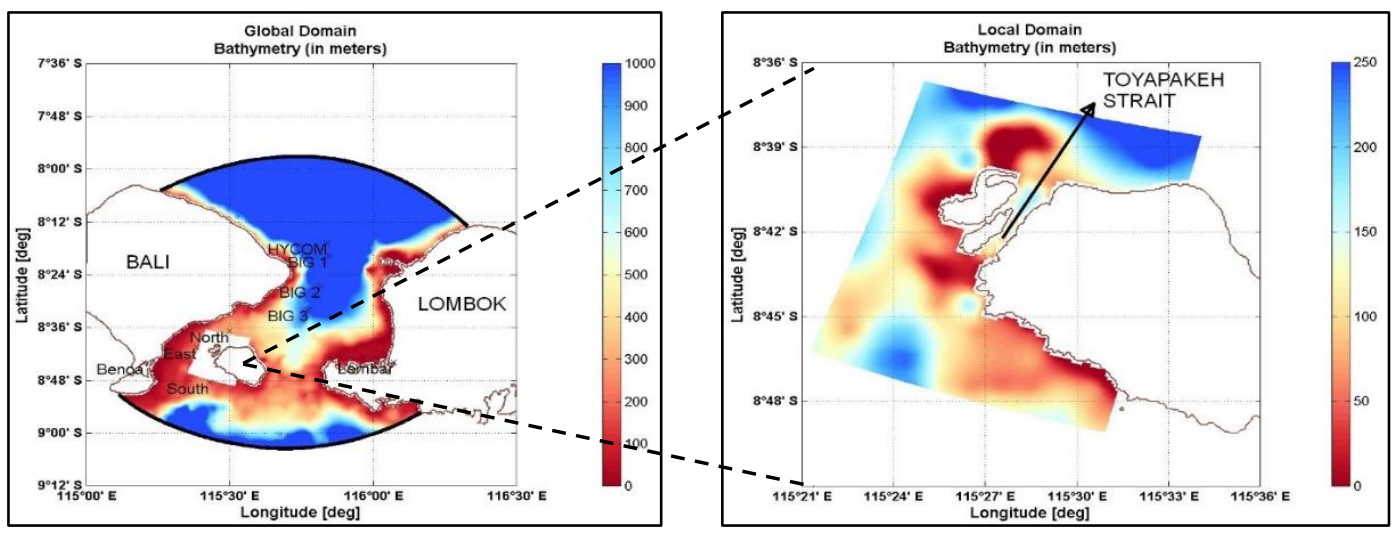

(a)

(b)

Figure 1. The hydrodynamic modelling overview of a) Global Domain showing bathymetry in meters, open boundaries location (black lines) and model validation locations; b) Local Domain showing bathymetry in meters and Toyapakeh Strait location. 


\section{Levelized cost of energy calculation}

Economic value of a farm of tidal turbine is evaluated using the Levelized Cost of Energy (LCOE). According to Arinaldo and Pujantoro (2019), the LCOE considers the ratio of net present value of the cost, including the capital cost $\left(I_{t}\right)$, operational and maintenance cost $\left(M_{t}\right)$, and fuel cost if necessary, and adjusted energy production $\left(E_{t}\right)$ as shown in equation (4)

$$
L C O E=\frac{\sum_{t=1}^{n} \frac{I_{t}+M_{t}}{(1+r)^{t}}}{\sum_{t=1}^{n} \frac{E_{t}}{(1+r)^{t}}}
$$

\section{Result and Discussion}

\section{Model validation}

Model validation is performed to measured model reliability. In water level validation, model output is compared against data in 2 observation stations (i.e., Benoa and Lembar) and 6 points of tidal prediction provided by the Indonesian Geospatial Agency as shown in Figure 1 (BIG, 2020). The averaged error is $2.32 \%$ showing a good model reliability, with each value shown in Table 1. Velocity validation is rather complicated due to data availability. Since there is no observation data obtained, predicted data from HYCOM ocean model is used (HYCOM, 2020). The modelled and predicted velocities at $-8.28^{\circ}$ Latitude and $115.84^{\circ}$ Longitude (HYCOM in Figure 1) are compared and resulting $21.12 \%$ error. Time series comparison is shown in Figure 2 where both data presenting similar patterns and trends.
Table 1. Summary of errors in water elevation validation.

\begin{tabular}{cccc}
\hline \multirow{2}{*}{ Station } & \multicolumn{2}{c}{ Coordinate } & \multirow{2}{*}{ Error (\%) } \\
\cline { 2 - 3 } & Lat $\left({ }^{\circ}\right)$ & Long $\left({ }^{\circ}\right)$ & \\
\hline Benoa & -8.7333 & 115.2000 & 3.79 \\
Lembar & -8.7309 & 116.0723 & 5.15 \\
BIG 1 & -8.3276 & 115.8454 & 1.96 \\
BIG 2 & -8.4425 & 115.8146 & 1.70 \\
BIG 3 & -8.5318 & 115.7760 & 1.52 \\
North & -8.6130 & 115.4980 & 1.46 \\
South & -8.8080 & 115.4290 & 1.23 \\
East & -8.6750 & 115.3840 & 1.73 \\
\hline \multicolumn{4}{c}{ Mean Error Value } \\
\hline
\end{tabular}

\section{Model output}

Spatial velocity at rising and falling water level on spring and neap cycle which visualized in Figure 3 is analyzed to found potential sites with constant highspeed flow. The high-speed can be observed during a condition where the water level at the mean level, occurring between the high and low water or vice versa. According to Figure 3, high-speed flow constantly occurs at the Southern side of Toyapakeh Strait. Potential sites are determined within this area, selected base on the velocity distribution and power generation.

Six cells shown in Figure 4 presents promising velocity. Velocity distribution at each cell is visualized by the frequency distribution graph shown in Figure 5. According to the figure, cell 5 and cell 6 have a preferable velocity distribution. The graph for both points peaks at 1.5 to $2.5 \mathrm{~m} . \mathrm{s}^{-1}$
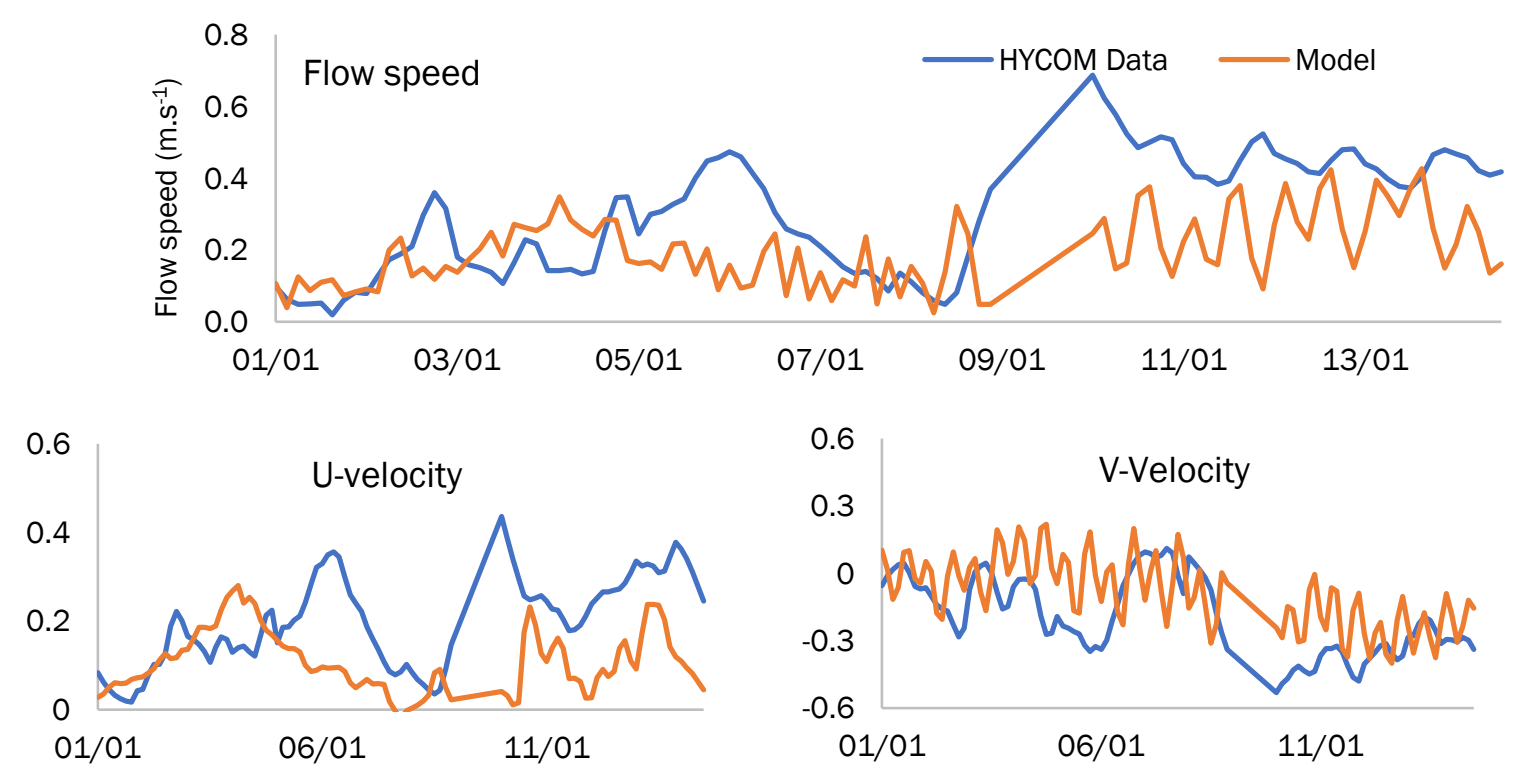

Figure 2. Comparison of the computed model and the prediction data from HYCOM (2020) 
ILMU KELAUTAN: Indonesian Journal of Marine Sciences September 2021 Vol 26(3):155-162
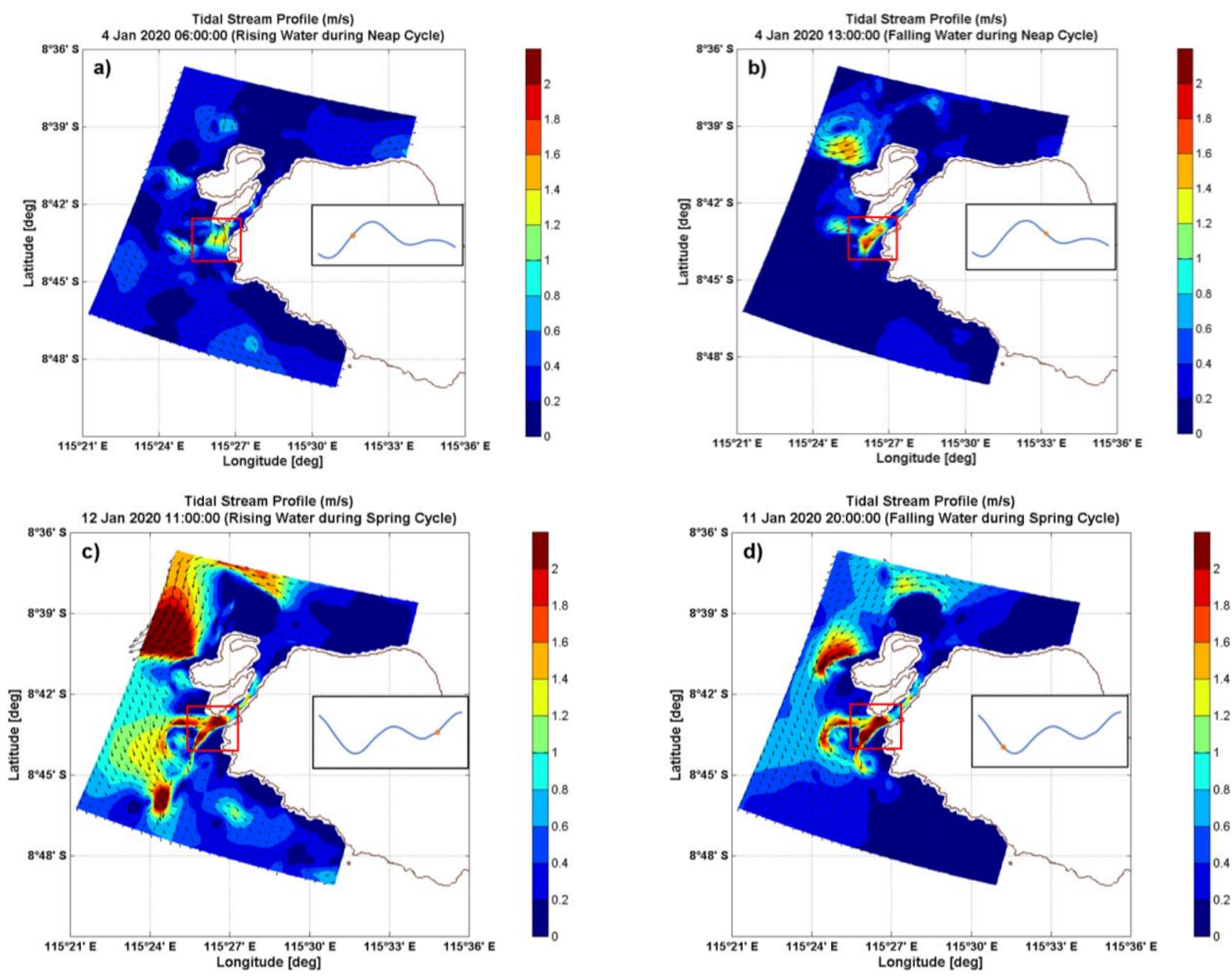

Figure 3. Tidal stream profile at the potential area (red box) showing a) rising water during neap cycle; b) falling water during neap cycle; c) rising water during spring cycle and d) falling water during spring cycle.

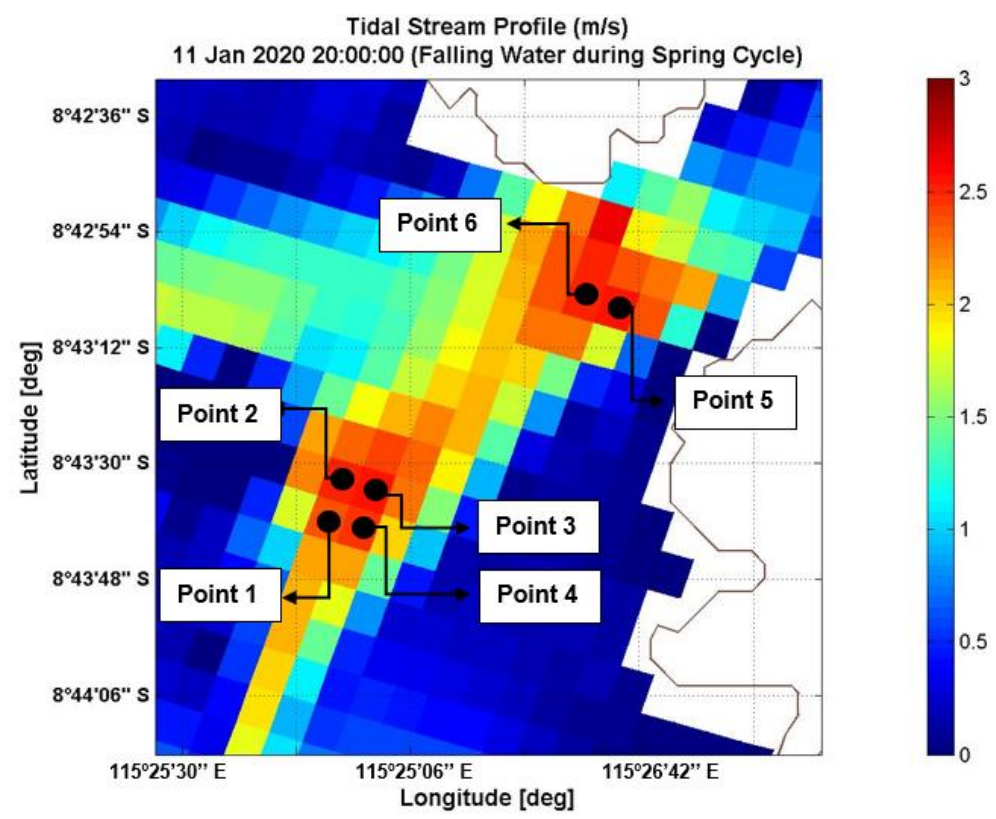

Figure 4. More detail tidal stream profile at the potential area showing falling water during spring cycle. 


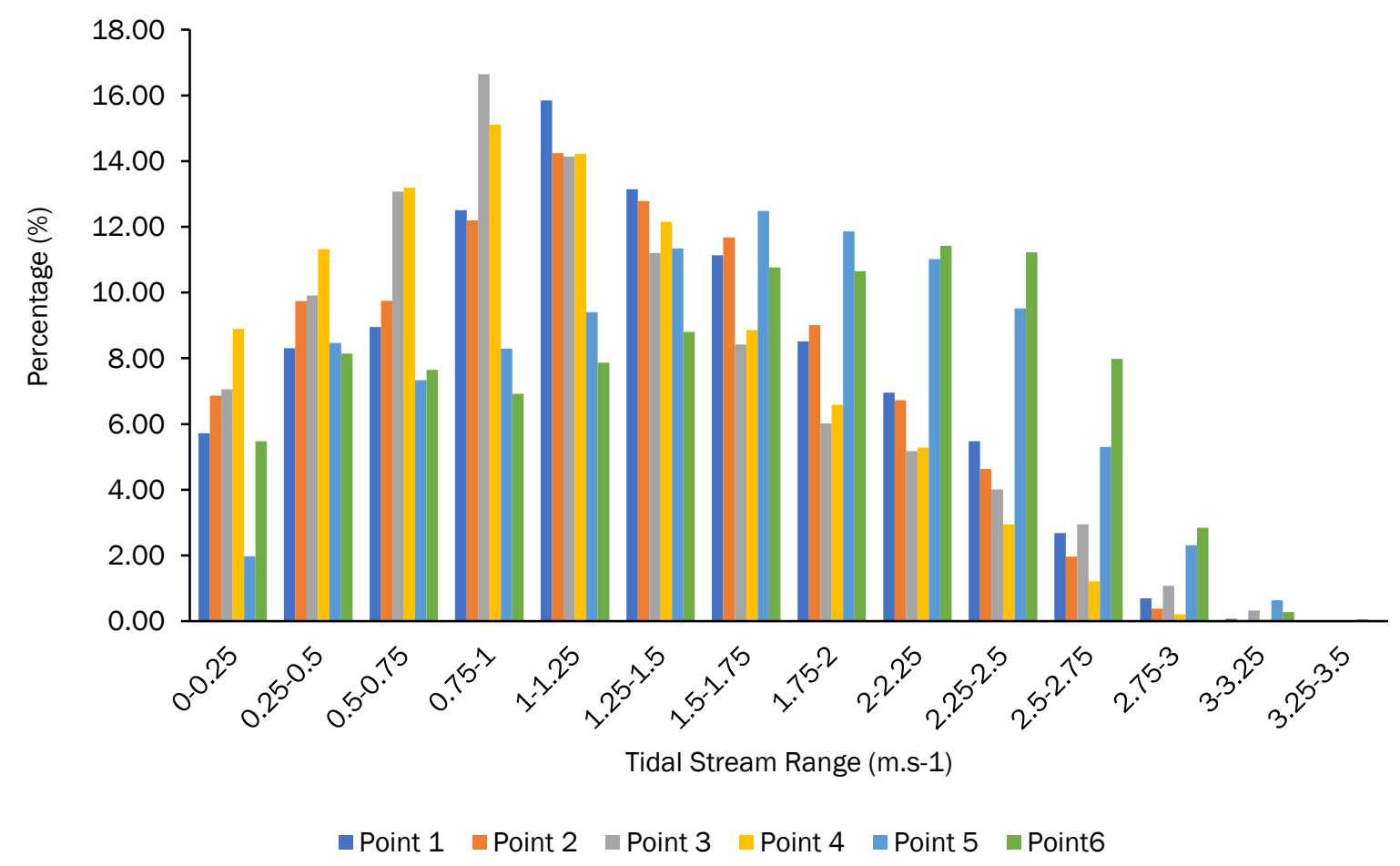

Figure 5. Frequency distribution of velocities at potential area

\section{Power production}

One of the state-of-art tidal stream turbine technology is Gen5 KHPS, developed by Verdant Power with $38 \%$ total efficiency. This turbine fits the environmental condition of the potential site with $5 \mathrm{~m}$ diameter and suitable operating speed range, $1 \mathrm{~m} . \mathrm{s}^{-1}$ to $3.3 \mathrm{~m} . \mathrm{s}^{-1}$ (Verdant, 2019).

Based on the calculation, the annual mean powers of cell 5 and cell 6 are 28.84 kW.unit ${ }^{-1}$ and $28.35 \mathrm{~kW}$.unit-1, respectively. Due to this consideration, cell 5 will be chosen as the farm location. Figure 6 shows typical power production in one spring-neap cycle. With this rate of power production, a Gen5 KHPS in cell 5 can produce up to 253.4 MWh annually. To supply Tiga Nusa annual electricity demand, a total of 21 units of Gen5 KHPS is needed to produce up to $5.3 \mathrm{GWh}$.

\section{Financial viability}

The cost estimation analysis consists of fabrication, installation, operational, and maintenance. The costs in year 2020 are shown in Table 2 (Verdant, 2019). These prices increase yearly assuming inflation rate at $2.97 \%$ (BPS, 2020).

The adjusted prices are used to calculate the LCOE. The net present value of total expenditures in 25 years is 495.59 Billion Rupiahs, and the tidal turbine farm produces 81.6 million $\mathrm{kWh}$. Therefore, the LCOE calculation results in Rp 6,072.33 per kWh of electricity or equivalent to $\$ 0.41 . \mathrm{kWh}^{-1}$. Annually, the farm generates 32.46 billion rupiahs revenue.

Table 2. Tidal turbine farm cost per item. CAPEX and OPEX are Capital Expenditure and Operational Expenditure.

\begin{tabular}{cccr}
\hline Item & Cost Type & & \multicolumn{1}{c}{ Cost (2020) } \\
\hline Fabrication & CAPEX & $\mathrm{Rp}$ & $235,283,047,908.43$ \\
Installation & CAPEX & $\mathrm{Rp}$ & $98,161,011,241.26$ \\
Maintenance & OPEX & $\mathrm{Rp}$ & $17,947,288,700.00$ \\
Operational & OPEX & $\mathrm{Rp}$ & $3,780,000,000.00$ \\
\hline
\end{tabular}

In Indonesia, electricity prices are governed in Regulation of the Minister of Energy and Mineral Resources of Republic of Indonesia Number 4 Year 2020 (ESDM Regulation No. 4 Year 2020). Electricity generated by renewable plants can get incentive with higher prices than the conventional ones. Marine based electricity production in Toyapakeh Strait can be sold at $\mathrm{Rp} 2,348 . \mathrm{kWh}^{-1}$ maximum. Hence, the LCOE of the proposed tidal turbine farm is still high.

The expenditure is dominated by the fabrication cost, at $46 \%$. Whereas turbine manufacture accounts for $97 \%$ of total fabrication cost (Verdant, 2019), indicating that the price of the turbine influence the project cost significantly, so does the number of the installed turbine. Further, a 


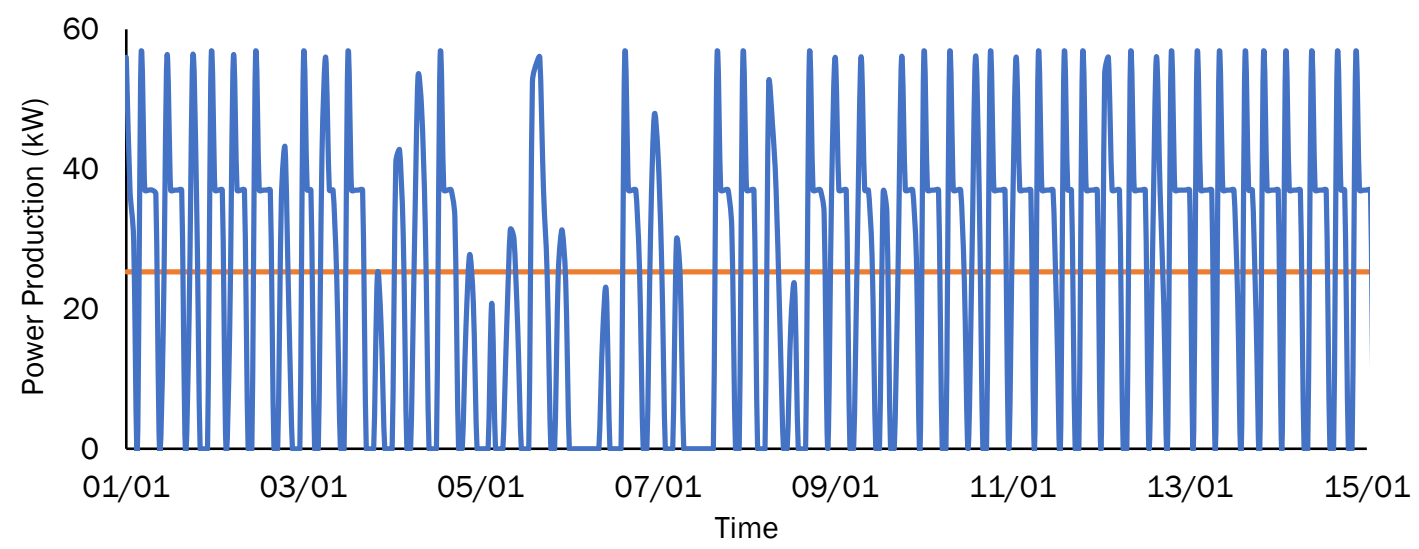

Figure 6. Power production on 1-15 January 2020. The horizontal line at $25.3 \mathrm{~kW}$ marks the average power production.

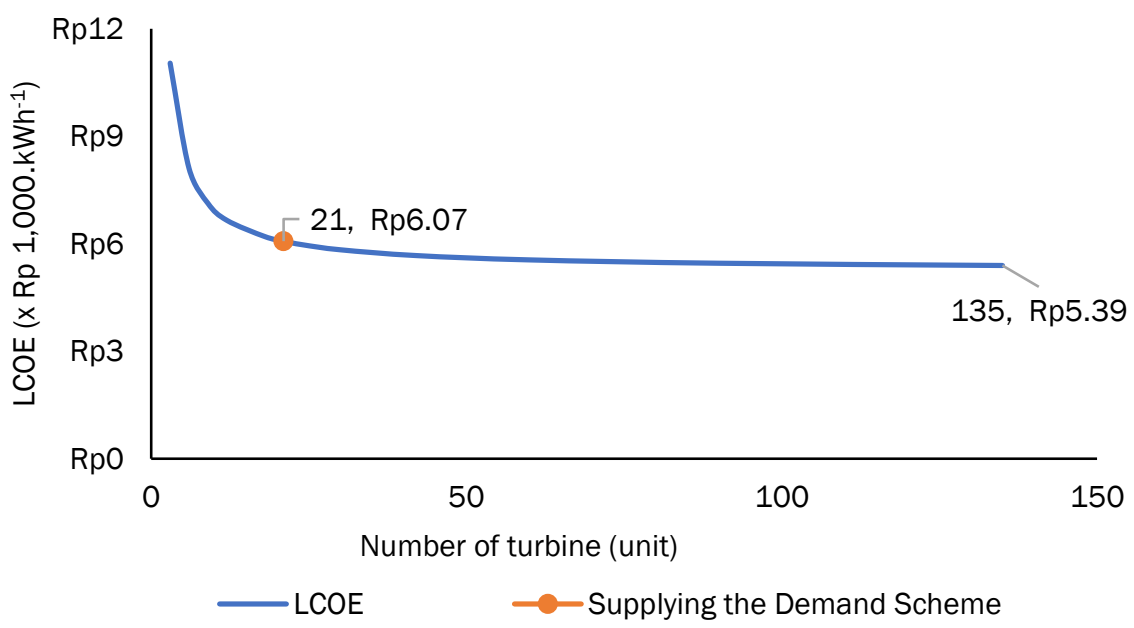

Figure 7. LCOE by number of turbine variable.

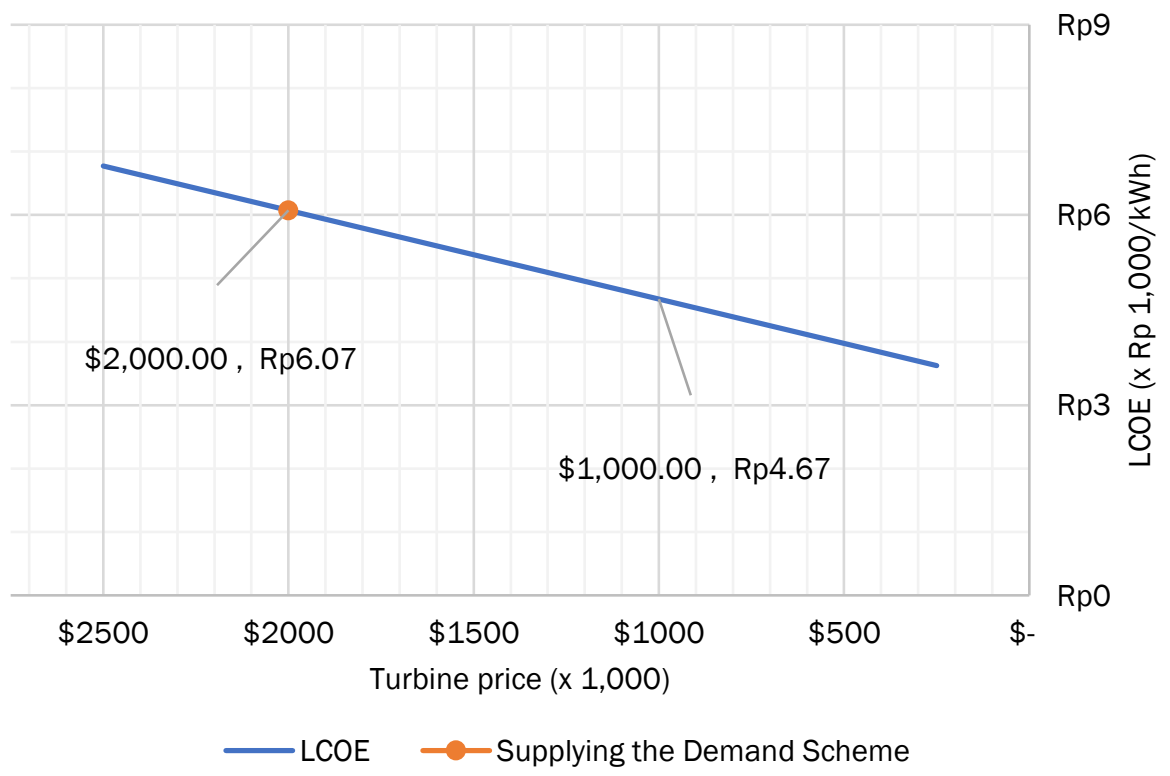

Figure 8. LCOE by turbine price variable 
sensitivity analysis for the number and the prices of turbine is carried out. It is found that the LCOE is lessened if more turbines are installed as presented in Figure 7, but the lower limit is Rp 5,390.kWh-1. While the LCOE reduces around $\mathrm{Rp} 1,400 . \mathrm{kWh}^{-1}$ when the turbine prices reach half price as presented in Figure 8.

The analysis indicates that the high price of electricity production is a result of the high cost of turbine technology. Tidal stream turbine technology is one of new emerging technology. As the technology developed into higher level of maturity, it is expected that the manufacture cost will be reduced significantly.

\section{Conclusion}

Numerical modelling using Delft3D-FLOW performed for Nusa Tiga Islands Cluster shows a good reliability and suggesting that the Southern side of Toyapakeh strait contains an energetic flow. A tidal stream turbine farm at $-8.7181^{\circ}$ Latitude and $115.4440^{\circ}$ Longitude with 21 units of Gen5 KHPS is proposed to supply electricity demand of the islands. The generated electricity is $17.74 \mathrm{GWh}$ annually. The generated electricity costs Rp 6,072.33. kWh-1 (\$ $0.41 . \mathrm{kWh}^{-1}$ ) with 25 years analysis period which is still relatively expensive, especially in Indonesia. The breakdown of total expenditure indicates that turbine manufacture holds a crucial role in determining the electricity tariff. Reduction of $50 \%$ of turbine cost cut the tariff about Rp 1,400. $\mathrm{kWh}^{-1}$ and it is expected as the turbine technology advanced, the manufacturing cost could be reduced significantly.

\section{Acknowledgement}

The authors gratefully acknowledge the support and contributions of the Ocean Engineering Program, Faculty of Civil and Environmental Engineering, Institut Teknologi Bandung and Deltares' open-source software for the numerical modelling.

\section{References}

Ajiwibowo, H., Lodiwa, K.S., Pratama, M.B. \& Wurjanto, A. 2017a. Field measurement and numerical modeling of tidal current in Larantuka Strait for renewable energy utilization. Int. J. GEOMATE, 13(39): 124-131. doi: 10.21660/ 2017.39.98548

Ajiwibowo, H., Lodiwa, K.S., Pratama, M.B. \& Wurjanto, A. 2017b. Numerical Model of Tidal Current for Power Harvesting in Bangka Strait. Int. J. Earth Sci. Engineering, 10(04): 833-843. doi: 10.21276/ijee.2017.10.0415
Arinaldo, D. \& Pujantoro, M. 2019. Levelized Cost of Electricity di Indonesia Saat Ini. Jakarta: Institute for Essential Services Reform (IESR).

BIG [Badan Informasi Geospasial]. 2020. Real time tidal observation. http://tides.big.go.id:8888/ dash/

Badan Pusat Statistik [BPS]. 2020. Indeks Harga Konsumen dan Inflasi Bulanan Indonesia. Retrieved from Web Site Badan Pusat Statistik: https://www.bps.go.id/statictable/2009/06/1 5/907/indeks-harga-konsumen-dan-inflasibulanan-indonesia-2006-2020.html

Deltares. 2020a. Delft3D-FLOW, User Manual. Deltares. $690 \mathrm{pp}$.

Deltares. 2020b. Delft3D Open Source Community. https://oss.deltares.nl/web/delft3d/home

Egbert, G.D. \& Erofeeva, S.Y. 2002. Efficient inverse modeling of barotropic ocean tides. J. Atmospheric and Oceanic Technol., 19(2): 183204.

ESDM Decree No. 4421, Penetapan Provinsi Bali sebagai Kawasan Nasional Energi Bersih [The Designation of Bali Province as a Clean Energy National Area]. (2015). https://jdih.esdm.go.id/ peraturan/Kepmen-esdm-4421-2015.pdf

ESDM Regulation No. 4, Perubahan Kedua atas Peraturan Menteri Energi dan Sumber Daya Mineral Nomor 50 Tahun 2017 tentang Pemanfaatan Sumber Energi Terbarukan untuk Penyediaan Tenaga Listrik [The Second Amendment to the Regulation of the Minister of Energy and Mineral Resources Number 50 of 2017 about the Utilization of Renewable Energy Sources for the Electricity Provision]. (2020). https://drive.esdm.go.id/wl/?id=fnJmTTrDi2xK BxoxmygdYhjp9JCQmB8t

Fikri, M. \& Hudaya, C. 2018. Studi Optimasi Pembangkit Listrik Berbasis Energi Terbarukan pada Sistem Kelistrikan Pulau Nusa Penida Bali. SENTER Seminar Nasional Teknik Elektro, 2018: 265-275.

Firdaus, A.M., Houlsby, G.T. \& Adcock, T.A.A. 2017. Opportunities for tidal stream energy in Indonesian Waters. Proceedings of the $12^{\text {th }}$ EWTEC, Cork: Ireland.

Firdaus, A.M., Houlsby, G.T. \& Adcock, T.A.A. 2019. Resource estimates in Lombok Straits, Indonesia. Proceedings of the 13th EWTEC, Napoli: Italy. 
Firdaus, A.M., Houlsby, G.T. \& Adcock, T.A.A. 2020. Tidal energy resource in Larantuka Strait, Indonesia. Proc. Institution of Civil Engineers Energy, 173(2):81-92. doi: 10.168 0/jener.19. 00042

GEBCO. 2020. General Bathymetric Chart of the Oceans. https://www.gebco.net/

Hardisty, J. 2009. The Analysis of Tidal Stream Power. West Sussex: John Wiles \& Sones Ltd.

HYCOM. 2020. Global Ocean Forecasting System (GOFS). https://www.hycom.org/dataserver/go fs-3pt1/analysis

IRENA. 2017. Renewable energy prospects: Indonesia, a Remap analysis. International Renewable Energy Agency (IRENA), Abu Dhabi. www.irena.org/remap

Kurniawan, A., Hasan, G.M.J., Ooi, S.K., Kit, L.W., Loh, L.L. \& Bayen, S. 2014. Understanding hydrodynamic flow characteristics in a model mangrove ecosystem in Singapore. APCBEE Procedia, 10:286-291. doi: 10.1016/j.apcbee.20 14.10.054

Kurniawan, A., Mujahidin, B. \& Idris, K. 2018. Analyzing harbor location and orientation based on waves conditions: A case study at west of Borneo. International Association for HydroEnvironment Engineering and Research (IAHR)Asia Pacific Division (APD) Congress: MultiPerspective Water for Sustainable Development, 1: 1-441.

Mangestiyono, W., Setyoko, B. and Tadeus, D.Y., 2019. Mechanical Strength of $10 \mathrm{~kW}$ Wind Turbine Blade Utilize Glass Fiber Reinforced Plastic. Materials Today: Proceedings, 13: 71-75.
Mukhtasor, Susilohadi, Erwandi, Pandoe, W.W., Iswadi, A., Firdaus, A.M., Prabowo, H., Sudjono, E., Prasetyo, E. \& Ilahude, D. 2014. Potensi Energi Laut Indonesia. Asosiasi Energi Laut Indonesia (ASELI), Jakarta. 1-56.

Orhan, K., Mayerle, R., Narayanan, R., \& Pandoe, W.W. 2016. Investigation of the energy potential from tidal stream currents in Indonesia. Proc. Coast. Engineering Conference, 35(1):1-10 doi: 10.9753/icce.v35.management.10

Orhan, K., \& Mayerle, R. 2020. Potential hydrodynamic impacts and performances of commercial-scale turbine arrays in the strait of Larantuka, Indonesia. J. Mar. Sci. Engineering, 8(3):.223. doi: 10.3390/jmse8030223

Pratama, M.B., Venugopal, V., Ajiwibowo, H., Ginting, J.W., \& Novico, F. 2020. Modelling tidal flow hydrodynamics of Sunda Strait, Indonesia. IImu Kelautan: Indonesian Journal of Marine Sciences, 25(4):165-172. doi: 10.14710/ik. ijms.25.4.165-172

Rachmat, B. \& Ilahude, D. 2017. Estimasi Potensi Energi Arus Laut Dengan Menggunakan Perhitungan Model Turbine Arus Poros Horizontal di Selat Toyapakeh, Nusa Penida, Bali. Bull. Mar. Geology, 32(2):51-60.

Tay, S.H.X., Kurniawan, A., Ooi, S.K. \& Babovic, V. 2016. Sea level anomalies in straits of Malacca and Singapore. Applied Ocean Research, 58: 104-117. doi: 10.1016/j.apor.2016.04.003

Verdant, P. 2019. Final License Application for New License Rosevelt Island Tidal Energy Project FERC No. 12611 Exhibit Environmental Report. New York: Verdant Power. 